\title{
Carbon Footprint of Transitional Shelters
}

\author{
Matti Kuittinen $^{1} \cdot$ Stefan Winter ${ }^{2}$
}

Published online: 28 September 2015

(c) The Author(s) 2015. This article is published with open access at Springerlink.com

\begin{abstract}
Extreme weather events, sea level rise, and political disputes linked to climate change are driving masses to leave their homes. Their transitional settlements should be produced in a manner that causes minimum greenhouse gas (GHG) emissions to prevent any further acceleration of climate change and the humanitarian crises it causes. This article presents a study of the carbon footprint and primary energy demand of the construction materials of eight different transitional shelters. The lowest carbon footprints were found from shelter models made from bamboo or timber. The highest emissions were caused by shelters that have either a short service life or that are made from metal-intensive structures. The choice of cladding materials was surprisingly important. The findings were further compared to the overall impacts of each construction project, to national per capita GHG emissions, and to construction costs. Some shelter projects had notable total energy consumption even compared to the annual energy use of industrialized countries. The study concludes that construction materials have an important impact on the carbon footprint of shelters. Comparisons should however be made only between similar functional units. Furthermore, benchmark values and more background data are urgently needed in order to give humanitarian nongovernmental organizations tools for lowering the carbon footprint of their construction operations.
\end{abstract}

Matti Kuittinen

matti.kuittinen@aalto.fi

1 Department of Architecture, School of Arts, Design and Architecture, Aalto University, 00076 Aalto, Finland

2 Faculty of Civil, Geo and Environmental Engineering, Technische Universität München, 80333 Munich, Germany
Keywords Carbon footprint - Humanitarian construction · Lifecycle assessment · Primary energy

\section{Introduction}

It is not common to carry out assessments of carbon footprint in the field of humanitarian construction. The following section includes viewpoints that explain the relevancy and timely importance of science-based environmental assessment in humanitarian work.

\subsection{Are Carbon Footprint and Energy Efficiency Relevant in Humanitarian Construction?}

The primary objective of humanitarian aid is to save lives, alleviate suffering, and maintain human dignity. However, this noble task inevitably causes environmental impacts as a side effect. For instance, energy is needed to transport food or medicines. Greenhouse gas (GHG) emissions are caused when blankets or tents are manufactured with the help of fossil energy. These manmade GHG emissions are the main cause of ongoing climate change (IPCC 2014). Global warming has links to loss of arctic sea ice (Stroeve et al. 2007), sea level rise (Hansen et al. 2013), changes in weather (UNISDR 2012), and finally a growing number of refugees (Christian Aid 2007). Extreme weather conditions seem to become more common and as many ecosystems, also human systems, are highly vulnerable to them (IPCC 2014). Storms and cyclones cause losses of life and property. Droughts force people to find new areas for their livelihood and increase competition for scarce resources. Warming temperatures can cause diseases to spread further, as for example the habitat for mosquitoes carrying malaria is expanding. Therefore, it would be necessary to 
optimize the environmental impacts of humanitarian aid without jeopardizing the aid itself.

\subsection{The Importance of Carbon Footprinting}

Carbon footprint (CF) can be understood as a "sum of greenhouse gas emissions and removals in a product system, expressed as $\mathrm{CO}_{2}$ equivalent and based on life cycle assessment" (ISO 2013, p. 1), although several definitions exist (Wiedmann and Minx 2007). For practical reasons, the global warming potential (GWP) of various greenhouse gases (methane, nitrous oxide, hydro fluorocarbons, and so on) is usually converted into corresponding GWP of carbon dioxide and expressed as kilograms of carbon dioxide equivalents $\left(\mathrm{kg} \mathrm{CO}_{2} \mathrm{e}\right)$. The amount of $\mathrm{CO}_{2}$ in the atmosphere has increased rapidly during the industrial era. The content of $\mathrm{CO}_{2}$ in the atmosphere is now higher than ever during the existence of human kind on earth (Pagani et al. 2010). In only a couple of centuries, the atmospheric $\mathrm{CO}_{2}$ has risen from $300 \mathrm{ppm}$ to around $400 \mathrm{ppm}$ (NOAA 2014).

Mitigating the amount of $\mathrm{CO}_{2}$ is important for several reasons: First, it is the most influential of all greenhouse gases because of its significant and increasing quantities (NOAA 2014). Second, it stays in the atmosphere for long periods of time. Around $20 \%$ of an impulse of $\mathrm{CO}_{2}$ emitted today would continue causing global warming even after 500 years (Hansen et al. 2013). Third, mankind still has the possibility to "turn down the heat", by lowering GHG emissions from fossil-fuel use and land-use change, as repeatedly proposed by the World Bank (2012a, 2013). After all, there is nobody else in this solar system to reduce GHG emissions on our behalf.

Humanitarian shelters can be made from several material combinations. A shelter made from steel, wood, bricks, straw, or plastic can fulfill the same minimum requirement that has been set for humanitarian work (The Sphere Project 2012). But the emissions that are caused when these shelters have been manufactured may differ greatly.

\subsection{Growing Primary Energy Demand is Causing more Emissions}

Primary energy (PE) is energy in nature that has not been transformed in any means. For example, oil, wood, sunlight, and wind are carriers of energy. When we try to take advantage of this natural primary energy, there are always losses in its efficiency. For example, production of solar electricity cannot generally yield more than $18 \%$ of the available primary solar energy (Repo et al. 2013, p. 950).

Different energy carriers enable different efficiencies of utilizing primary energy. Because of this, the energy efficiency can be expressed as primary energy efficiency. It describes how much of the available energy potential was actually utilized in the end-use.

Based on the statistics of International Energy Agency (IEA 2012), the energy needs of our planet are largely satisfied by burning fossil fuels. In 2010, around $81 \%$ of the world's total primary energy was made using fossil fuels.

As fossil fuels are burned, they emit $\mathrm{CO}_{2}$ into the atmosphere. Since this $\mathrm{CO}_{2}$ originates from the Earth's crust and not from the natural circulation of carbon in forests, soil, and seas, it accelerates global warming. Thus, both primary energy use and carbon footprint are tightly linked to climate change.

Shelters can be made of materials that require very little primary energy for their production. Such materials help to mitigate the growth of the primary energy demand and the emissions that are caused along with it.

\subsection{Focus on the Construction Sector}

The construction sector is globally accountable for around $30 \%$ of GHG emissions and around $40 \%$ of primary energy use (UNEP 2009). Buildings are seen to hold the greatest estimated economic mitigation potential for reducing GHG emissions (IPCC 2007). Only by measuring the amount of $\mathrm{CO}_{2}$ emissions for construction products is one able to define how environmentally harmful the selected combination of materials within a building will be.

The assessment of the environmental sustainability of construction works is often based on international standards. The ISO 14040 standard suite (ISO 2006) for lifecycle assessment (LCA) forms a basis for several furtherdeveloped standards. ISO 21930 (ISO 2007) and EN 15804 (CEN 2012) give guidelines for developing environmental product declarations for construction products. EN 15978 (CEN 2011) outlines rules for the sustainability assessment of construction work. Several voluntary green labeling schemes for buildings have also been developed. For example, LEED (USA, global), BREEAM (UK, global), HQE (France), DGNB (Germany), CASBEE (Japan), and GBL (China) all offer different approaches for assessing and communicating the environmental impacts of a building.

Several studies about the carbon footprint and primary energy demand of modern construction have been conducted. Gustavsson and Sathre (2011) summarized the steps essential in the lifecycle assessment of a building. Häkkinen (2012) and Häkkinen et al. (2015) developed reference values for sustainability and performance assessment of buildings. Ruuska et al. (2013) compared the environmental impacts of building materials. Guggemos and Horvath (2005) have studied the lifecycle aspects of alternative concrete and steel structures. The carbon 
footprint of several wood-framed buildings have been calculated and analyzed according to ISO and EN standards (Kuittinen et al. 2013). Environmental impacts on residential neighborhoods have also been analyzed in detail, by using, for example, economic input-output assessment methods (Heinonen et al. 2012).

Despite the great number of carbon footprint studies that have been performed and normative standards that have been developed, there is not adequate scientific information about the environmental impacts or GHG emissions of humanitarian construction. Therefore, this article presents the carbon footprint and primary energy demand analyses of eight transitional shelters. Needs for further methodological development and practical implementation are drawn as conclusions.

\section{Methodology}

The methods that were used for this study are presented in the following. Main approaches are based on lifecycle assessment, with focus on the production phase of construction materials.

\subsection{Scope and Goal}

There were two aims for the study: (1) To assess greenhouse gas emissions and the primary energy demand of eight different shelter designs. (2) To investigate how suitable LCA-based carbon footprinting is in a humanitarian context. Humanitarian construction can be divided into three phases: emergency, transitional, and reconstruction. This study focuses on the transitional phase.

\subsubsection{Covered Lifecycle Phases}

In order to communicate which part of the buildings lifecycle is the most dominant in an environmental assessment, the lifecycle has been arranged (EN 15643-2:2011) into four main and 17 sub-modules as follows (Table 1).

The lifecycle assessment can be carried out for these entire stages - "cradle to grave" —or only for the construction materials of the building _ "cradle to gate". In the latter, it is possible to include parts of other modules as well (EN 15978:2011).

The required information for calculating the environmental impacts for modules A1-A3 can usually be gathered from a bill of quantities of the designed building. All further modules require scenarios of construction methods, tools, technical service life, maintenance strategy, renovation, deconstruction methods, recycling options, and waste management with associated logistics and storing. Therefore, estimations for modules from A4 and A5 to C may be more prone to uncertainties, as it is not exactly possible to know how the building will, in practice, be maintained during its lifespan or what type of waste management options will be available thereafter. Drafting reliable scenarios for the lifecycle of the building is especially demanding in the context of humanitarian construction or developing countries. For instance, the service life of a transitional shelter is short when compared to conventional buildings, ranging from some months to some years in most cases. This causes different dominance of lifecycle modules and challenges traditional thinking of the order of their importance (Hafner et al. 2012). Furthermore, a war, tsunami, or earthquake may damage infrastructure so severely that reconstruction of waste management or energy infrastructure may take an entirely different direction than before the incident. As an example, the national energy mix in Japan changed considerably after the Great East Japan Earthquake and Tsunami, because nuclear power plants were idled and natural gas imported as a replacing source of energy (NPR 2012). This gave the national energy mix a higher GHG intensity than before the disaster.

Drafting reliable scenarios for the lifecycle of a building requires professional LCA assessors, who are used to working with databases and setting scenarios. This article focuses only on the tasks of the humanitarian project team, and is therefore limited to module A1-A3 (cradle to gate).

Use-phase energy demand and end-of-life scenarios will be studied separately in the future. Efforts will be made to reconstruct reliable scenarios for the full lifecycle (modules A-C) and additional consequential benefits or drawbacks of selected shelters (module D).

\subsubsection{Functional Unit}

Functional units are $\mathrm{m}^{2}$ of living area and estimated service life. A functional unit helps to compare different objects of study. It describes the amount of emissions released per chosen unit. Otherwise, the results would not be comparable, because larger buildings would need more materials and thus cause more environmental loads. On the other hand, a building that lasts longer may, during its full lifecycle, cause less environmental impact than a building that is made from more environmentally friendly building materials but that can be used only for a shorter period of time.

\subsubsection{Service Life}

Estimated service life was taken from the assumptions given in the case reports of the studied shelter designs. No further scenarios were developed. In reality, storms or floods may lead to shorter service lives of certain building 
Table 1 Lifecycle phases according to EN 15643

\begin{tabular}{|c|c|c|c|c|}
\hline \multirow[t]{5}{*}{ A } & \multirow[t]{3}{*}{ Production } & Raw material supply & A1 & \multirow[t]{3}{*}{ Included in this study } \\
\hline & & Transport to factory & A2 & \\
\hline & & Manufacturing & A3 & \\
\hline & \multirow[t]{2}{*}{ Construction } & Transport to site & A4 & \multirow{13}{*}{$\begin{array}{l}\text { Not included in this } \\
\text { study due to lack of data }\end{array}$} \\
\hline & & Construction work & A5 & \\
\hline \multirow[t]{7}{*}{ B } & \multirow[t]{7}{*}{ Use } & Use & B1 & \\
\hline & & Maintenance & B2 & \\
\hline & & Repair & B3 & \\
\hline & & Replacement & B4 & \\
\hline & & Refurbishment & B5 & \\
\hline & & Operational energy use & B6 & \\
\hline & & Operational water use & B7 & \\
\hline \multirow[t]{4}{*}{$\mathrm{C}$} & \multirow[t]{4}{*}{ End of life } & Deconstruction & $\mathrm{C} 1$ & \\
\hline & & Transport & $\mathrm{C} 2$ & \\
\hline & & Waste processing & $\mathrm{C} 3$ & \\
\hline & & Disposal & $\mathrm{C} 4$ & \\
\hline $\mathrm{D}$ & Additional & Benefits and loads beyo & & \\
\hline
\end{tabular}

parts. Similarly, reusing construction components in a downgraded function may give them longer service life than initially planned.

\subsection{Inventory}

Inventory is based on the bills of quantities provided by the International Federation of Red Cross and Red Crescent Societies (IFRC 2011). Presumably the inventory may not be quite as accurate as required by LCA standards (ISO 14040 series), as it was not intended for making an LCA. It was not possible to assess individual shelters in detail, as that would have required travelling to locations across the globe to interview constructors.

\subsection{Impact Assessment}

Because it was not possible to track back global warming potential and primary energy demand from the production of the particular construction materials in the studied shelters, reference values for construction materials from a database were used. The chosen database was the Inventory of Carbon and Energy (ICE 2.0) by the University of Bath (2011). Despite its limitations-for instance, it excludes the carbon storage of wood material and does not have values for vernacular building materials (such as bamboo, coconut wood) - the ICE database is publicly available and could thus easily be accessed by the humanitarian consultants and organizations. Supplementary information for assessing the carbon footprint of bamboo was adapted from the LCA study of bamboo by Vogtländer (2011) and for the assessment of its embodied energy from Reiner et al. (2007).

The biogenic carbon storage of wood and other biobased materials is an important topic to be included in this study. According to European standards (EN 16485:2014) (CEN 2014), if wood originates from a sustainably managed forest, its biogenic component to global warming potential is negative. If wood is harvested from a forest for which sustainable management cannot be assumed, the products biogenic carbon balance over time is considered to be zero, but it adds to the global warming potential of the product (EN 16485:2014, 6.3.4.2) (CEN 2014). In our study, it was not possible to investigate the origin of wood, bamboo, or coconut in the assessed shelters. Therefore, we have separately calculated both GWP scenarios for wooden frames: sustainably sourced and non-sustainably sourced. For bamboo and coconut we have applied the same scenarios and calculated their biogenic carbon content as for wood material.

Carbon storage of wood and bio-based products helps to mitigate climate change. The atmospheric carbon stays locked in such material until it decays naturally or is burned for energy. However, in our study, we exclude the positive impact of carbon storage because according to standards (EN 16485:2014, 6.3.4.4.2) (CEN 2014) the benefits of storing carbon in a product are shown in lifecycle module B1 as technical scenario information, and this module is outside the system boundary of our study.

It has to be pointed out that regardless of how norms guide us to communicate carbon storage, it is still an important phenomenon that helps to mitigate climate 
change and therefore should be kept in mind when considerations for the sustainability of construction materials are made.

\subsection{Interpretation of Results}

Results were studied through comparing assessment findings.

(1) The scales of total emissions of relief projects were compared to each other and to annual total energy use and carbon emissions of a cold industrialized country in northern Europe (Finland).

(2) The GHG emissions of constructing transitional shelters were compared to national annual per capita GHG emissions.

(3) The joint impact of GHG emissions and material costs (carbon economy) of shelters were compared.

Conventionally, LCA studies would include sensitivity analysis and normalization of results. They were not included in the scope of this article.

\subsection{Uncertainties and Limitations}

There are a number of uncertainties in the study. Locating them was actually one of the goals of the assessment.

\subsubsection{Quality of Data}

It seems to be very difficult, if not impossible, to get reliable environmental data about vernacular construction materials that are used in developing countries. Several bamboo species, coconut wood, and various local tree species are not typically listed in environmental databases. For this study, the following commercial or open source databases were checked: ICE 2.0, IBO, KBOB, Idemat 2010, and ecoinvent 2.2. Furthermore, consistent information about the density and dry mass calculations of these materials seems to be hard to find. Such values would be needed for the assessment of sequestered atmospheric carbon in the material.

Due to the lack of data, conservative assumptions were made. Primary energy and carbon footprint values for coconut and other local tree species were replaced with general soft wood values of ICE 2.0. Carbon storage was excluded from the study. The biogenic component to the global warming potential was calculated by using densities for wood-based materials from the ecoinvent 2.2 database.

The used database is compiled from the sources of developed countries and thus reflects the environmental impacts of production facilities and raw material acquisition in developed countries. Without a separate study, it cannot be known how great a difference there would be to the figures that would be gathered from industrial processes in developing countries. The level of manual work is supposedly higher, but the implementation of environmentally friendly manufacturing technologies is presumably lower. Therefore, in this study, it has been assumed that the positive environmental gains from manual work are offset by the emissions of less environmentally friendly industrial processes.

\subsubsection{Accuracy of Inventory}

Due to practical reasons, it was not possible to travel and check the exact construction of each shelter type. Nor is there information about possible variation in the construction of similar shelter types. The great number of shelters built would indicate that there is likely a variance in detailing, materials, and even dimensioning of individual shelters. Thus, the inventory may not fully reflect an average shelter of each type.

The inventory and impact assessment were checked twice. Although reasonable effort has thus been made to ensure that no errors would distort the results, such may always occur in lifecycle assessment.

\subsubsection{Exclusion of Carbon Storage, Feedstock Energy, and Land-Use Change}

Due to the previously explained reasons, both carbon storage and the embodied feedstock energy of wood were left out of the study. Had they been considered, the results would have been more favorable for wood and bamboobased shelters.

On the other hand, the consequential effects of using wood from possibly non-sustainably managed forests were also left out. The consequential effects may have an impact in a wider system analysis. However, they should be taken into account regarding all materials, if a consequential LCA would be made in the future.

GHG emissions associated to direct or indirect land-use change have been left outside of this study. The required amount of data could not be gathered within this study. Furthermore, there is no commonly agreed scientific method for quantifying land-use related GHG emissions (Mattila et al. 2011).

\section{Studied Transitional Shelters}

The selected shelter models are all published by the International Federation of Red Cross and Red Crescent Societies (IFRC) in Transitional Shelters-8 Designs (IFRC 2011). All shelters have been built during the last 10 years in various parts of the world, many of them in 
great numbers. The materials of the shelters have been arranged into the following building part categories for this study:

- Foundation

- Main structure (load-bearing frame)

- Secondary structure (supporting frame for coverings)

- Coverings (external and internal claddings)

- Fixings (nails, screws, straps, etc.)

The shelter models differ from each other in many ways (Table 2). Their functional and structural design cannot be compared. However, they all fulfill the fundamental function of temporary housing. The main differences that affect the studied environmental impacts include:

- Living area

- Construction materials

- Estimated service life

- Cost of materials

GHG emissions and PE demand that are linked to the manufacturing of these building parts were estimated.

\section{Results}

Results from the assessment are presented in this section. We report carbon footprint calculations for two alternative material sourcing scenarios: sustainably sourced and non-sustainably sourced wood and bamboo. Also primary energy calculations are presented.

\subsection{Carbon Footprints Differ According to Chosen Materials}

The results are shown with two different functional units: $\mathrm{m}^{2}$ of living area and estimated service life. In addition, two alternative scenarios are presented: base scenario without calculating the climate benefits of sustainably sourced wood and comparative scenario showing the positive impacts of sustainable forestry (SF).

Findings clearly show the dominant impact of coverings in nearly all shelters. A majority of the shelters had coverings made of steel or plastic, which both cause remarkable $\mathrm{CO}_{2} \mathrm{e}$ emissions when compared to other assessed materials. This trend can be seen regardless of functional units (Fig. 1). Also, the negative impact of concrete foundations is shown in the results. Manufacturing of concrete generates considerable GHG emissions.

The most environmentally friendly shelter seems to be the Indonesian model Shelter no. 1. Its structures are mainly made from bamboo, which is renewable material. Although the GHG emissions of the used bamboo are based on adaptive simulations from other studies, as explained earlier, it can be assumed with reasonable certainty that the emissions are very low.

Also, timber-based shelters from Peru (Shelter no. 4 and 5) seem to perform well in GHG comparison. This is due to the low global warming potential of wood material. In their case, a majority of emissions come from concrete foundations. When considering the climate benefits of sequestered atmospheric carbon of sustainably sourced wood material, these shelters perform even better.

It has to be noted that although uncertainties can distort the results, the trend is likely to be even stronger if possible replacements of coverings during the lifespan of the shelter would have been included in the study. It is likely that, especially in cyclone-prone areas, parts of the coverings would need to be replaced during the estimated service lives of the shelters.

A similar amplifying effect might also be caused, if the carbon storage capacity would have been taken into account. While trees and bamboos grow, they absorb $\mathrm{CO}_{2}$ from the atmosphere. This biogenic carbon is stored in construction materials until it will be released back into the atmosphere in energy recovery (incineration) or natural decay. This inherent material property of wood and

Table 2 Information of shelters

\begin{tabular}{|c|c|c|c|c|c|c|c|c|}
\hline & $\begin{array}{l}\text { Frame } \\
\text { material }\end{array}$ & $\begin{array}{l}\text { Units } \\
\text { built }\end{array}$ & Year & $\begin{array}{l}\text { Living } \\
\text { area }\left(\mathrm{m}^{2}\right)\end{array}$ & $\begin{array}{l}\text { Service } \\
\text { life (yrs.) }\end{array}$ & $\begin{array}{l}\text { Set-up } \\
\text { (days) }\end{array}$ & $\begin{array}{l}\text { Set-up } \\
\text { (persons) }\end{array}$ & $\begin{array}{l}\text { Material } \\
\text { cost (USD) }\end{array}$ \\
\hline Shelter 1, Indonesia, Java & Bamboo & 430 & 2009 & 24 & $1-5$ & $3-4$ & $3-4$ & 281 \\
\hline Shelter 2, Indonesia, Sumatra & Timber & 7,000 & 2009 & 18 & 1 & 2 & 5 & 393 \\
\hline Shelter 3, Pakistan & Stone & 10,000 & 2010 & 18 & 2 & 1 & 4 & 561 \\
\hline Shelter 4, Peru & Timber & 2,020 & 2007 & 18 & 2 & 1 & 4 & N/A \\
\hline Shelter 5, Peru & Timber & 3,000 & 2007 & 18 & 1 & 2 & 4 & 253 \\
\hline Shelter 6, Haiti & Steel & 5,100 & 2010 & 18 & 2 & 2 & N/A & 1,908 \\
\hline Shelter 7, Indonesia, Aceh & Steel & 20,000 & 2004 & 25 & 5 & 3 & 4 & 5,348 \\
\hline Shelter 8, Vietnam & Steel & 215 & 2004 & 26 & 5 & 3 & 5 & N/A \\
\hline
\end{tabular}

Prices have been converted from Swiss Franc (CHF) to US dollars (USD), rate 1-1.12237 


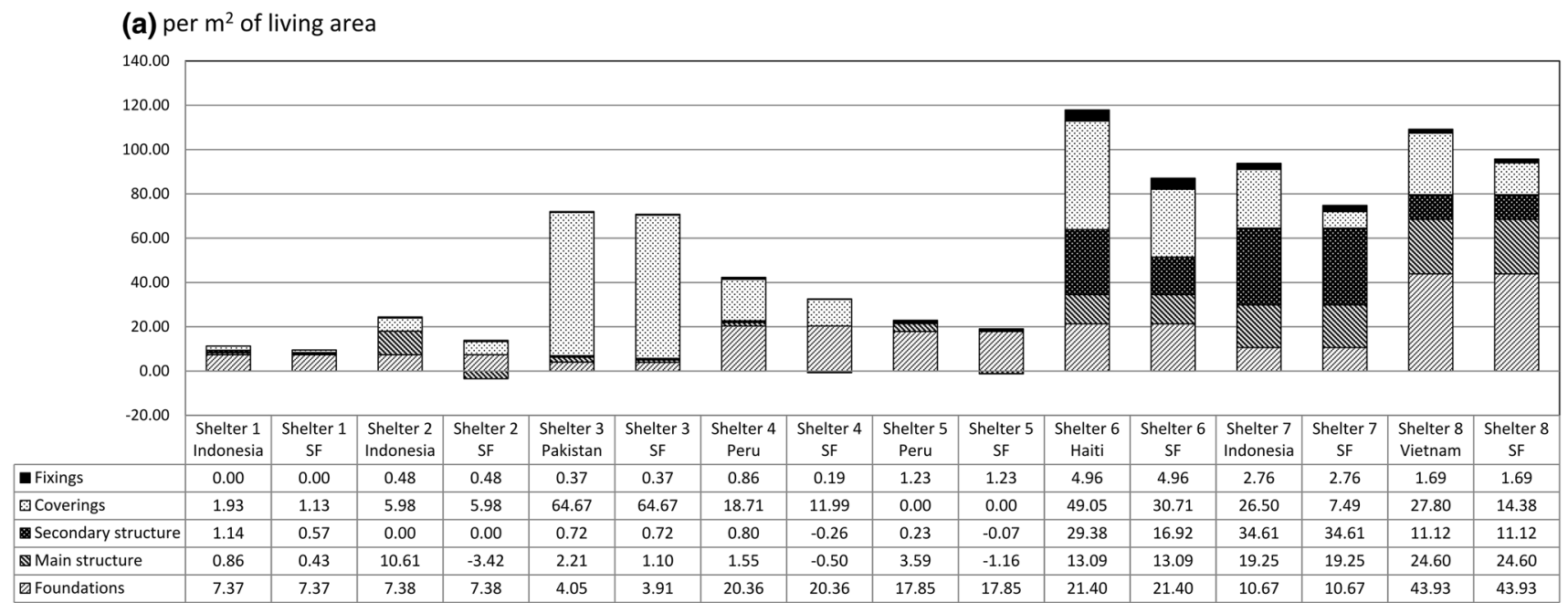

(b) per years of service life

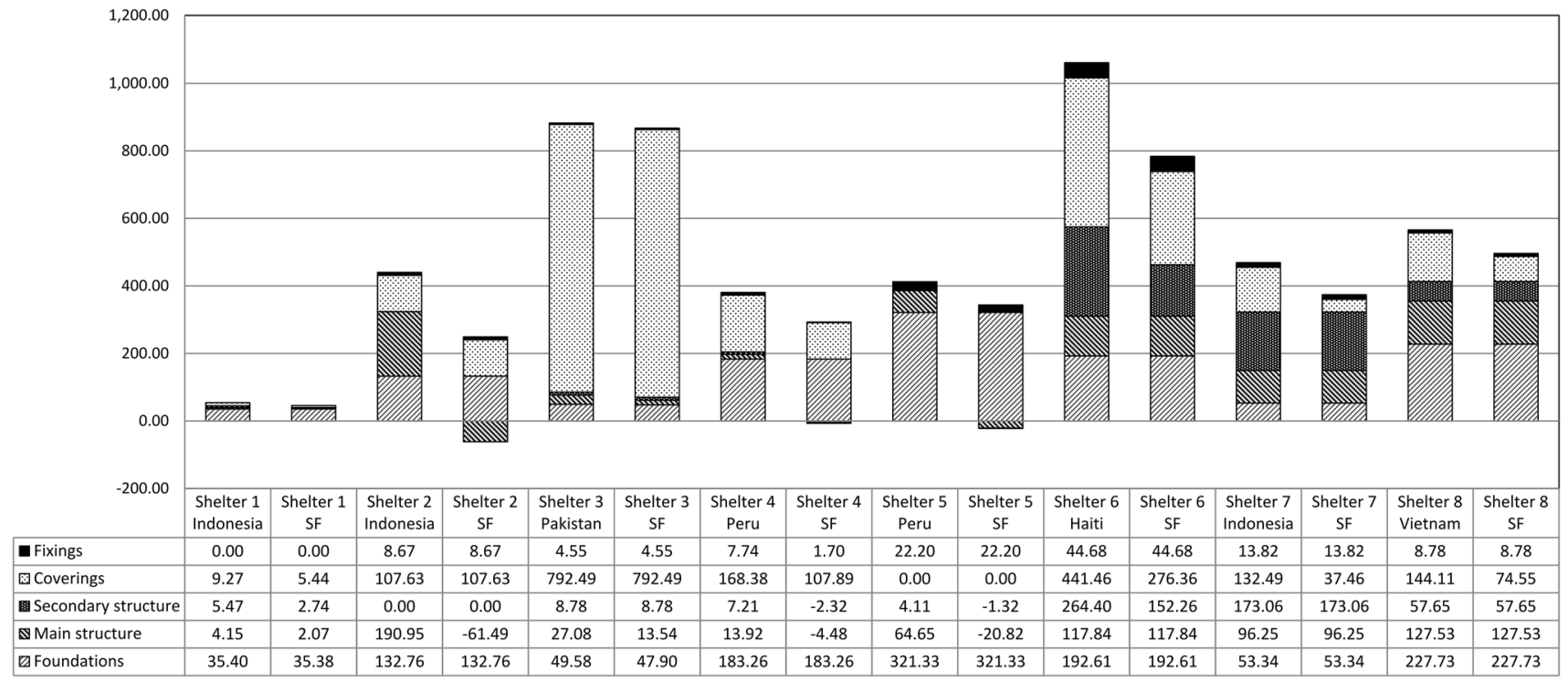

Fig. 1 Greenhouse gas emissions of the studied shelters using two alternative functional units $\left(\mathrm{m}^{2}\right.$ and service life). Note the impact of comparative scenario (SF) that demonstrates the impact of using sustainably sourced wood material

bamboo helps to mitigate climate change-assuming that it does not lead to deforestation due to illegal or un-sustainable forestry practices.

It is interesting to observe the impact of assuming sustainable forestry in the GWP of wooden frames. For example, the total GWP of the primary structures of Shelters 2, 4, and 5 turns negative.

\subsection{Primary Energy Demand Stays Low if Bio- Based Materials are Used}

The consumption of primary energy follows the same pattern as the carbon footprint. The major impact of coverings can again be clearly noticed, as well as the better performance of timber-based shelters (Fig. 2).
The best of the shelter solutions seems to be Indonesian Shelter no. 1. It has a high amount of bamboo as construction material. Primary energy demand on bambooalthough there are uncertainties-is far smaller than for steel products, which add the energy demand for shelters in Haiti (no. 6), Indonesia (no. 7), and Vietnam (no. 8).

The findings would be even more dramatic if the energy potential of wood, bamboo, and plastics would be taken into account. In the end of the life span of the shelters, their bio-based and oil-based materials could be recycled into energy by burning them. If this end-of-life benefit would have been taken into account, the share of steel-cladding caused primary energy use would have been even more dominant. However, burning wood or bamboo for energy results in biogenic GHG emissions that can be assumed 
(a) MJ per $\mathrm{m}^{2}$ of living area

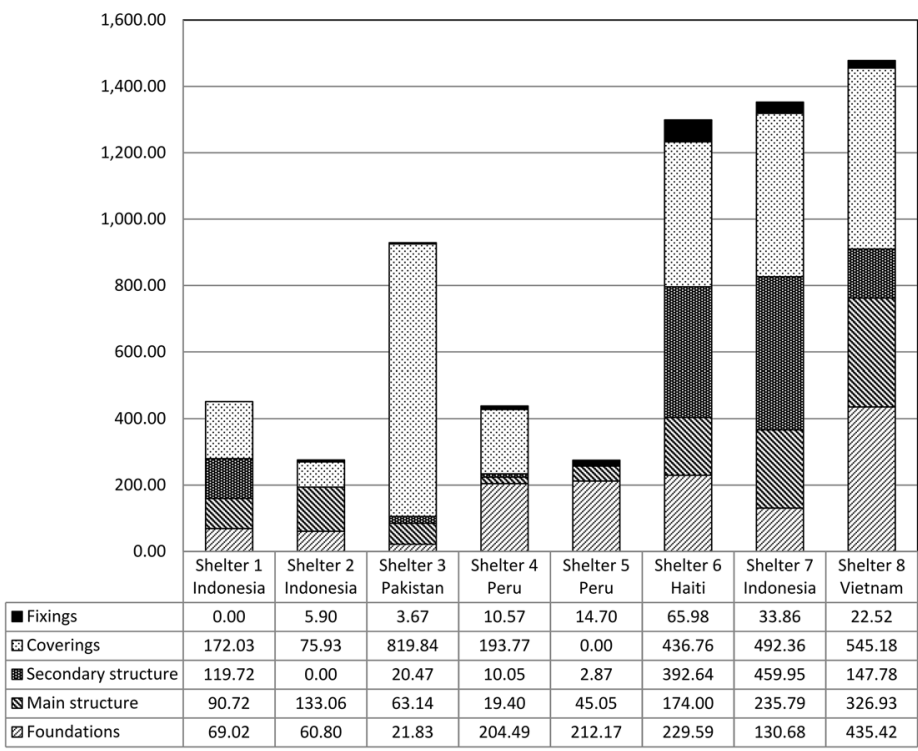

(b) MJ per estimated service life

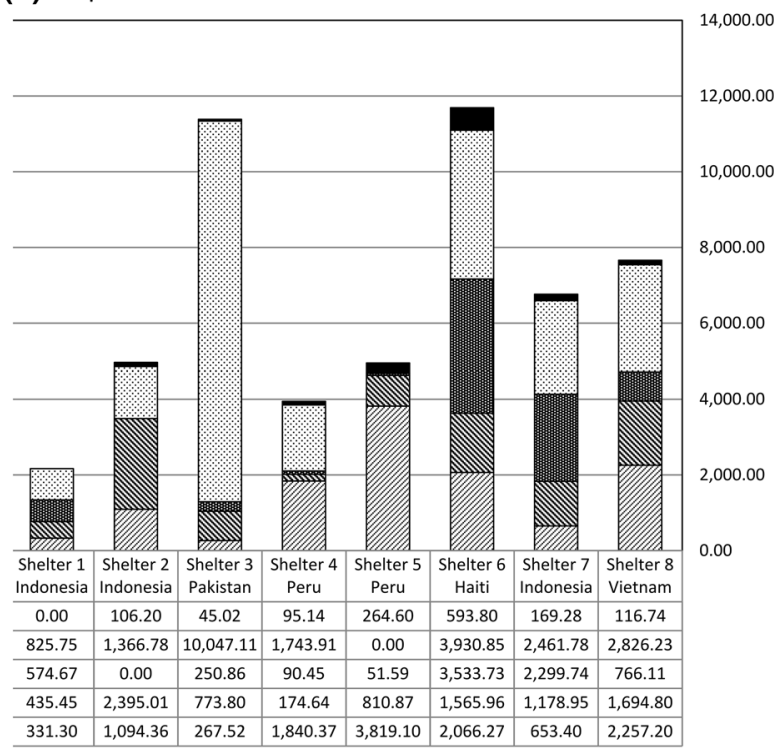

Fig. 2 Primary energy demand per $\mathrm{m}^{2}$ and service life. The impact of coverings is significant in most cases

Table 3 Total GHG emissions of selected projects

\begin{tabular}{lccc}
\hline Shelter type & Units built & GHG emissions $\left(\mathrm{kg} \mathrm{CO}_{2} \mathrm{e}\right)$ & Primary energy demand (MJ) \\
\hline Shelter 3, Pakistan & 10,000 & $17,649,645$ & $227,686,209$ \\
Shelter 7, Indonesia & 20,000 & $12,310,813$ & $176,777,158$ \\
Shelter 6, Haiti & 5,000 & $11,277,850$ & $125,300,971$ \\
\hline
\end{tabular}

carbon neutral if the materials originate from sustainable sources (EN 16485:2014) (CEN 2014). Burning oil-based plastics causes fossil GHG emissions that are an additional burden to the natural carbon cycles of our planet.

It should also be mentioned that steel used in structures can be recycled into other uses after the shelter is no longer in use. Thus, the primary energy demand for making virgin steel products would be avoided, and environmental balance would be slightly milder for the share of steel and aluminum products (University of Bath 2011). These benefits are however outside of our system boundary.

Most likely, all of the raw materials for shelters would not be manufactured in their use areas. Manufacturing energy demand would cause impacts only in the areas of manufacturing units. Depending on the energy mix of the factories, different environmental impacts are caused. For example, production of aluminum requires plenty of energy. That can be sourced, for example, from coal plants or wind turbines. They represent practically opposite ends in the greenhouse gas emissions required for producing 1 $\mathrm{kWh}$ of energy.

A full lifecycle approach would be needed to conclude the operative energy demand of the given shelters. Including heating energy demand would raise the impact of shelters that are located in a cool climate. Most likely, shelters from Pakistan and Peru would show more PE demand during their operational phase.

\section{How Should the Results be Understood?}

The results describe the GHG emissions and PE demand from the production phase of the construction materials of the transitional shelters. The results show the dominance of cladding and roofing materials. But are the figures good or bad? Where can they be compared to? In the following, three alternative benchmarking approaches are presented: (1) Overall impacts of a project; (2) Per capita GHG emissions; and (3) Carbon economy.

\subsection{Overall Impacts of Each Shelter Project}

The total climate impacts of shelter projects were compared by multiplying the GHG emissions and PE demand by the number of shelters (Table 3 ). It has to be noted again that there are most likely differences in the material combination of shelters in large projects. Such variations have not been simulated in the study due to high 
Table 4 GHG emissions per capita $\left(\mathrm{kg} \mathrm{CO}_{2} \mathrm{e}\right)$

\begin{tabular}{|c|c|c|c|c|c|c|}
\hline & $\begin{array}{l}\text { a. GHG per } \\
\text { Capita (national } \\
\text { averages } \\
\text { from statistics) }\end{array}$ & $\begin{array}{l}\text { b. Share of } \\
\text { construction sector } \\
\text { (national averages } \\
\text { from statistics) }(\%)\end{array}$ & $\begin{array}{l}\text { c. Household } \\
\text { size (national } \\
\text { averages from } \\
\text { statistics) }\end{array}$ & $\begin{array}{l}\text { d. GHG } \\
\text { per household } \\
\text { from construction } \\
\left(\mathrm{a}^{*} \mathrm{~b}^{*} \mathrm{c}\right)\end{array}$ & $\begin{array}{l}\text { e. GHG of } \\
\text { materials } \\
\text { (as calculated } \\
\text { for each shelter) }\end{array}$ & $\begin{array}{l}\text { f. Ratio } \\
\text { e:d (\%) }\end{array}$ \\
\hline Shelter 1 , Indonesia & 1,800 & 13 & 4.5 & 1,053 & 271.44 & 26 \\
\hline Shelter 2, Indonesia & 1,800 & 13 & 4.5 & 1,053 & 440.01 & 42 \\
\hline Shelter 3, Pakistan & 900 & 14 & 6.41 & 807.66 & $1,719.89$ & 213 \\
\hline Shelter 4, Peru & 2,000 & 16 & 4.1 & 1,312 & 776.53 & 59 \\
\hline Shelter 5, Peru & 2,000 & 16 & 4.1 & 1,312 & 434.49 & 33 \\
\hline Shelter 6, Haiti & 200 & 5 & 3.4 & 34 & $2,211.34$ & 6,504 \\
\hline Shelter 7 , Indonesia & 1,800 & 13 & 4.5 & 1,053 & 615.54 & 58 \\
\hline Shelter 8, Vietnam & 1,700 & 13 & 3.8 & 839.8 & $2,872.94$ & 342 \\
\hline
\end{tabular}

uncertainties. The results of total impacts show the highest GHG emissions and PE demand as shown inTable 3.

The finding is interesting: Although the largest number of shelters was built in Aceh, Indonesia (no. 7), the shelters from projects in Pakistan and Haiti still reach the same or higher level of emissions. From a project-level viewpoint (top-down approach) this shows that the number of units built is not necessarily linearly related to their environmental impacts. Some construction material choices, as explained earlier, seem to cause significant emissions even in smaller projects.

From an energy viewpoint, the findings are slightly different. Although the most environmentally harmful shelter models are the same, their order changes. This is explained by the higher amount of steel and aluminum used in Indonesia and Haiti compared to the Pakistani shelters.

To understand the magnitude of GHG and PE impacts of individual projects, their total emissions and energy use were compared to corresponding annual statistic data of a European country, in this case Finland (Statistics Finland 2013, 2014). As a result, it was found that the GHG emissions from the Pakistani shelter project (no. 3) were $0.026 \%$ of all annual GHG emissions in Finland in 2013 (excluding emissions related to land use, land-use change, and forestry), and the PE demand for the manufacturing of the construction materials of the Indonesian shelter project (no. 7) was $0.013 \%$ of the annual energy used in Finland for the whole manufacturing sector during 2012. These can be considered as relatively high figures. The findings underline the environmental importance of choices that nongovernmental organizations (NGOs) make in humanitarian construction practices.

\subsection{Per Capita GHG Emissions of Shelters}

Global statistics are available on the per capita GHG emissions for each country. The World Bank (2012b), for instance, provides these statistics. Kuittinen (2015a) presented a method for setting benchmark levels for low carbon humanitarian construction: the emissions of humanitarian shelters are compared to the per capita GHG emissions of their countries. By applying this method, a context-sensitive benchmark may be found.

The share of construction sector related emissions from the annual per capita GHG emissions was retrieved from the open-source data of The Shift Project Data Portal (2013). The resulting figure is then multiplied by the average national household size in order to get an estimation for the GHG emissions of an average family. Then, this "GHG per household" value was compared to the GHG emissions of the construction materials of the shelter. This way it was possible to see how the building of a transitional shelter added to the average annual GHG emissions of people living in each of the studied countries.

From Table 4, it can be seen that some of the shelters made a significant addition to the per capita GHG emissions. The steel-framed and steel-covered shelter in Haiti (no. 6) especially shows remarkable addition to the average annual Haitian per capita GHG emissions. On the other hand, some shelters are made of materials that hardly add to the per capita figure at all-Indonesian bamboo and timber shelters are such examples. Because per capita GHG emissions vary significantly between countries, the values in Table 4 can only be compared with values from the same country.

\subsection{Carbon Economy of Shelters}

The source publication (IFRC 2011) of this study gives prices for materials and project of each shelter. This opens a possibility to define carbon economy or the joint impact of GHG emissions and material costs of a building (Kuittinen 2015b). Carbon economy of a shelter model can only be compared with other shelter models from the same area. 
Table 5 Carbon economy of shelters

\begin{tabular}{llll}
\hline & $\begin{array}{l}\text { a. Material } \\
\text { costs } \\
\left(\mathrm{USD} / \mathrm{m}^{2}\right)\end{array}$ & $\begin{array}{l}\text { b. GHG } \\
\text { from materials } \\
\left(\mathrm{kg} \mathrm{CO}_{2} \mathrm{e} / \mathrm{m}^{2}\right)\end{array}$ & $\begin{array}{l}\text { c. Carbon } \\
\text { economy a*b }\end{array}$ \\
\hline Shelter 1, Indonesia & 11.69 & 11.31 & 132.21 \\
Shelter 2, Indonesia & 21.82 & 24.45 & 533.40 \\
Shelter 3, Pakistan & 31.18 & 72.01 & 2245.27 \\
Shelter 4, Peru & Not available & 42.28 & - \\
Shelter 5, Peru & 14.03 & 22.90 & 321.36 \\
Shelter 6, Haiti & 106.00 & 117.89 & $12,496.08$ \\
Shelter 7, Indonesia & 213.92 & 93.79 & $20,063.86$ \\
Shelter 8, Vietnam & Not available & 109.14 & - \\
\hline
\end{tabular}

This is because material costs are different in different countries and disaster response actions.

From Table 5 we can see that there are large absolute differences between the construction costs of each shelter. However, the ratio of GHG emissions and construction costs allows one to compare shelters that are carried out in the same area or project. The values in Table 5 are higher if the material production of the shelter emitted high amounts of GHG and lower if the emissions are low.

\section{Conclusions and Future Work}

Conclusions from the study are drawn in the following section. They include summaries about environmental assessment in humanitarian construction, construction material choices, comparison of different shelters, and benchmarking of carbon footprint.

\subsection{Environmental Assessment in Humanitarian Construction is Important}

The results show that there are significant differences in the carbon footprint and PE demand of individual shelters and shelter projects. The comparisons to national per capita GHG emissions, construction costs, or to reference values from industrialized countries all indicate that there may be environmental gains available if action would be taken by humanitarian actors.

Therefore, the LCA-based environmental assessment processes should be further developed for the humanitarian context. Lack of relevant databases for LCA and scenarios for the full lifecycle of shelters especially casts a shadow of uncertainty over the carbon footprinting of shelters. Although results would have a higher degree of uncertainty in the beginning, there may be more benefits in adopting the LCA-based environmental assessment in humanitarian construction project planning and reporting.

\subsection{Materials Make a Difference}

Results show that cladding materials of the studied shelters cause a significant amount of greenhouse gas emissions and primary energy demand. The only difference can be seen in wood and bamboo clad shelters. The result is not surprising, because most shelters had a significant amount of metal components and metal claddings. As known, the manufacturing of metal products is energy intensive and thus causes more greenhouse gas emissions than the production of wood- or bamboo-based claddings. Still, the environmental dominance of claddings can be seen as a new finding.

Based on this study, it can be recommended that cladding materials especially need to be carefully selected. The findings in this study should not be used for judging one construction material better than the other. A wider consequential analysis would be needed, and still the results would likely be case-specific. The same structural and building physical performance can be achieved with various material combinations. As a general rule, however, it can be said that bio-based renewable construction materials are usually more environmentally friendly, as long as they are sustainably sourced.

Construction materials for shelters need to fulfill several functions: They need to be cost-efficient and easy to transport and assemble. Their service life in the climatic conditions of the shelter has to be adequate. They have to withstand possible storms and heavy ultraviolet radiation and temperature caused by the sun. Furthermore, shelter materials need to be recyclable or bio degradable without harmful emissions to land, water, or air.

In addition, the sourcing of wood material seems to be important for lowering the carbon footprint of shelters. If wood is sourced from sustainably managed forests, it has a negative biogenic component to the global warming potential. Therefore, selecting sustainably sourced timber can be recommended for low-carbon shelters, if transportation distances do not considerably change.

\subsection{Comparisons Should be made Between Functionally Similar Shelters}

To get exactly comparable results, shelters should fulfill the same functional, technical, and economical requirements. The shelters in this study do not seem to be comparable in these aspects. However, a previous study of alternative construction materials for reconstruction of schools in Haiti showed the advantage of recycled construction materials in humanitarian construction.

As the development of shelter models continues, it would be recommendable to compare shelter models that fulfill the same technical requirements with different 
construction material combinations and choose the optimal solution. Cost estimation could be carried out in the same process.

\subsection{Benchmarking is Required}

When the per capita GHG values or carbon economy of different shelters are evaluated, they can be placed in context. It would be advisable to compare either of these factors in larger humanitarian aid projects. Such comparisons may be especially suitable for the reconstruction phase and development projects where there are less time constraints.

Environmental impacts of construction materials for shelters need to be weighted in relation to their other benefits and drawbacks. However, given the high importance of climate change mitigation, the reduction of greenhouse gas emissions and primary energy demand should be taken into consideration in coming shelter projects-especially if the number of shelters is high.

Acknowledgments The financial support of the Ruohonjuuri Fund, Finland has made this case study possible. Background material has been provided by Sandra D'Urzo from the International Federation of Red Cross and Red Crescent Societies (IFRC). We wish to thank all of the above mentioned for their kind help.

Open Access This article is distributed under the terms of the Creative Commons Attribution 4.0 International License (http://crea tivecommons.org/licenses/by/4.0/), which permits unrestricted use, distribution, and reproduction in any medium, provided you give appropriate credit to the original author(s) and the source, provide a link to the Creative Commons license, and indicate if changes were made.

\section{References}

CEN (European Committee for Standardization). 2011. EN 15978:2011. Sustainability of construction works: Assessment of environmental performance of buildings-Calculation method. Brussels: European Committee for Standardization

CEN (European Committee for Standardization). 2012. EN 15804:2012. Sustainability of construction works-Environmental product declarations-Core rules for the product category of construction products. Brussels: European Committee for Standardization.

CEN (European Committee for Standardization). 2014. EN 16485:2014. Round and sawn timber-Product category rules for wood and wood-based products for use in construction. Brussels: European Committee for Standardization.

Christian Aid. 2007. Human tide: The real migration crisis. A Christian Aid report. London: Christian Aid.

Guggemos, A., and A. Horvath. 2005. Comparison of environmental effects of steel and concrete framed buildings. Journal of Infrastructure Systems 11(2): 93-101.

Gustavsson, L., and R. Sathre. 2011. Energy and $\mathrm{CO}_{2}$ analysis of wood substitution in construction. Climatic Change 105(1-2): $129-153$.
Hafner, A., S. Winter, and A. Takano. 2012. Wooden products as building material in life cycle analysis. In Proceedings of the third international symposium on life-cycle civil engineering, 1530-1537. Vienna: Taylor \& Francis Group.

Hansen, J., P. Kharecha, M. Sato, V. Masson-Delmotte, F. Ackerman, D.J. Beerling, P.J. Hearty, O. Hoegh-Guldberg, et al. 2013. Assessing "dangerous climate change": Required reduction of carbon emissions to protect young people, future generations and nature. PLoS One 12(8). doi:10.1371/journal.pone.0081648.

Heinonen, J., A.-J. Säynäjoki, M. Kuronen, and S. Junnila. 2012. Are the greenhouse gas implications of new residential developments understood wrongly? Energies 5(8): 2874-2893.

Häkkinen, T. 2012. Sustainability and performance assessment of buildings-Final report. VTT publications 72. Espoo: VTT.

Häkkinen, T., M. Kuittinen, A. Ruuska, and N. Jung. 2015. Reducing embodied carbon during the design process of buildings. Journal of Building Engineering 4: 1-13.

IEA (International Energy Agency). 2012. Key world energy statistics. OECD/IEA, 2012. Paris: International Energy Agency

IFRC (International Federation of Red Cross and Red Crescent Societies). 2011. Transitional shelters-Eight designs. Geneva: International Federation of Red Cross and Red Crescent Societies.

IPCC (Intergovernmental Panel on Climate Change). 2007. Summary for policymakers. In Climate change 2007: Physical science basis. Contribution of Working Group I to the fourth assessment report of the Intergovernmental Panel on Climate Change, ed. S. Solomon, D. Qin, M. Manning, Z. Chen, M. Marquis, K.B. Averyt, M. Tignor, and H.L. Miller. Cambridge: Cambridge University Press.

IPCC (Intergovernmental Panel on Climate Change). 2014. Summary for policymakers. In Climate change 2014: Impacts, adaptation, and vulnerability. Part A: Global and sectoral aspects. Contribution of Working Group II to the fifth assessment report of the Intergovernmental Panel on Climate Change, ed. C.B. Field, V.R. Barros, D.J. Dokken, K.J. Mach, M.D. Mastrandrea, T.E. Bilir, M. Chatterjee, K.L. Ebi, et al., 1-32. Cambridge: Cambridge University Press.

ISO (International Organization for Standardization). 2006. ISO 14040:2006. Environmental management: Life cycle assessment-Principles and framework. Geneva: International Organization for Standardization.

ISO (International Organization for Standardization). 2007. ISO 21930:2007. Sustainability in building construction-Environmental declaration of building products. Geneva: International Organization for Standardization.

ISO (International Organization for Standardization). 2013. ISO/TS 14067:2013. Greenhouse gases-Carbon footprint of productsRequirements and guidelines for quantification and communication. Geneva: International Organization for Standardization.

Kuittinen, M., A. Dodoo, L. Gustavsson, D. Peñaloza, R. Sathre, A. Takano, F. Dolezal, O. Mair am Tinkhof, et al. 2013. Case studies. In Wood in carbon efficient construction, ed. M. Kuittinen, A. Ludvig, and G. Weiss, 112-152. Brussels: CEI-Bois.

Kuittinen, M. 2015a. Strategies for low carbon humanitarian construction. In Sustainable futures in a changing climate, ed. A. Hatakka and J. Vehmas, 366-372. FFRC eBook 2/2015.

Kuittinen, M. 2015b. Setting the carbon footprint criteria for public construction projects. Procedia Economics and Finance 21: $154-161$.

Mattila, T., T. Helin, R. Antikainen, S. Soimakallio, K. Pingoud, and H. Wessman. 2011. Land use and life cycle assessment. The Finnish Environment 24. Helsinki: SYKE. https://helda.helsinki. fi/handle/10138/37049. Accessed 14 May 2014. 
NOAA (National Oceanic and Atmospheric Administration). 2014. Trends in atmospheric carbon dioxide. http://www.esrl.noaa.gov/ gmd/ccgg/trends/global.html\#global_data. Accessed 21 May 2014.

NPR (National Public Radio). 2012. Nuclear woes push Japan into a new energy future. Interview of economist Mitsutsune Yamaguchi from University of Tokyo at NPR radio station, 11 March 2012. http://www.npr.org/2012/03/11/148136383/nuclear-woespush-japan-into-a-new-energy-future. Accessed 04 Aug 2014.

Pagani, M., Z.H. Liu, J. LaRiviere, and A.C. Ravelo. 2010. High earth-system climate sensitivity determined from Pliocene carbon concentrations. Nature Geoscience 3: 27-30.

Reiner, M., M. Pitterle, and M. Whitaker. 2007. How do you define green? Embodied energy considerations in existing LEED credits. http://www.oriental-bamboo.co.za/reference/embodied_ energy_considerations_in_existing_leed_credits.pdf. Accessed 14 May 2014.

Repo, P., J. Benick, G. von Gastrow, V. Vähänissi, F. Heinz, and J. Schön. 2013. Passivation of black silicon boron emitters with $\mathrm{ALD} \mathrm{Al}_{2} \mathrm{O}_{3}$. In Proceedings of the 3rd international conference on crystalline silicon photovoltaics, 950-954. 25-27 March 2013, Hamelin, Germany.

Ruuska, A., T. Häkkinen, S. Vares, M. Korhonen, and T. Myllymaa. 2013. Environmental impacts of building materials (Rakennusmateriaalien ympäristövaikutukset). Reports of the Ministry of the Environment 8. Helsinki: Ministry of the Environment (in Finnish).

Statistics Finland. 2013. Energy consumption in households. Helsinki: Statistics Finland. http://stat.fi/til/asen/2012/asen_2012_201311-13_tie_001_en.html. Accessed 10 Jun 2014.

Statistics Finland. 2014. Greenhouse gases. Helsinki: Statistics Finland. http://stat.fi/til/khki/index_en.html. Accessed 10 Jun 2014.
Stroeve, J., M.M. Holland, W. Meier, T. Scambos, and M. Serreze. 2007. Arctic sea ice decline: Faster than forecast. Geophysical Research Letters 34(9). doi:10.1029/2007GL029703.

The Shift Project Data Portal. 2013. Breakdown of GHG emissions by sector. http://www.tsp-data-portal.org/Breakdown-of-GHG-Emis sions-by-Sector\#tspQvChart. Accessed 10 Sept 2015.

The Sphere Project. 2012. The sphere handbook. http://www. spherehandbook.org. Accessed 5 Jun 2014.

UNEP (United Nations Environment Programme), Sustainable Buildings and Climate Initiative (SBCI). 2009. Buildings and climate change. Summary for decision makers. UNEP SBCI: 3. Nairobi: United Nations Environment Programme.

UNISDR (United Nations International Strategy for Disaster Reduction). 2012. Number of climate-related disasters around the world (1980-2011). http://www.preventionweb.net. Accessed 2 May 2014.

University of Bath, Sustainable Energy Research Team (SERT). 2011. Inventory of carbon and energy (ICE), version 2. http://www.bath. ac.uk/mech-eng/research/sert/. Accessed 14 May 2014.

Vogtländer, J. 2011. Life cycle assessment and carbon sequestration. Bamboo products of MOSO Internaltional. Delft, the Netherlands: TU Delft.

Wiedmann, T., and J. Minx. 2007. A definition of "Carbon footprint". $I S A^{U K}$ research report 07-01. Hauppage, NY: Nova Science Publishers.

World Bank. 2012a. Turn down the heat: Why a $4^{\circ} \mathrm{C}$ warmer world must be avoided. Washington DC: World Bank.

World Bank. 2012b. $\mathrm{CO}_{2}$ emissions (metric tons per capita). http:// data.worldbank.org/indicator/EN.ATM.CO2E.PC. Accessed 4 Apr 2014.

World Bank. 2013. Turn down the heat: Climate extremes, regional impacts and the case for resilience. Washington DC: World Bank. 